\title{
Post-escape dispersal of juvenile Atlantic cod Gadus morhua from Norwegian fish farms and their potential for recapture
}

\author{
R. M. Serra-Llinares ${ }^{1,2, *}$, R. Nilsen ${ }^{1,2}$, I. $_{\text {Uglem }^{3}}$, P. Arechavala-Lopez ${ }^{4}$ P. A. Bjørn ${ }^{1,2}$, \\ C. Noble ${ }^{1}$ \\ ${ }^{1}$ Nofima, Muninbakken 9-13, 9291 Tromsø, Norway \\ ${ }^{2}$ Institute of Marine Research, PO Box 6404, 9294 Tromsø, Norway \\ ${ }^{3}$ Norwegian Institute of Nature Research, Tungasletta 2, 7485 Trondheim, Norway \\ ${ }^{4}$ Department of Marine Science and Applied Biology, University of Alicante, PO Box 99, 03080 Alicante, Spain
}

\begin{abstract}
The escape of fish from sea-based aquaculture facilities is regarded as a potential environmental threat and is one of the biggest challenges the industry has faced in recent years. In addition to preventing escapes by improving farming operations and procedures, effective and operational routines are needed for recapturing fish should an escape occur. This study investigated the post-escape dispersal of juvenile Atlantic cod Gadus morhua L. from commercial sea cages in coastal Norway using acoustic telemetry. It also assessed the efficacy of different techniques (e.g. cod pots, fyke nets, and gill nets) for recapturing escaped fish. Results suggest that escaped juvenile cod can experience a high size-related predation pressure immediately after escape due to high numbers of large fish aggregating around the cages. Consequently, the escapees rapidly disperse from the farms and seek shelter in littoral areas. Once in shallower waters, they stay relatively close $(<10 \mathrm{~km})$ to the farm during the first 2 mo following an escape. This suggests a high potential for recapture if the effort is focused on the littoral area and not in the immediate vicinity of the farm. No escapees were caught using live recapture methods, and a low number of recaptures $(<5 \%)$ were achieved with gill nets deployed in littoral areas. Moreover, high by-catch rates and a subsequent high workload suggest this method may be inappropriate for the recapture of escapees.
\end{abstract}

KEY WORDS: Atlantic cod $\cdot$ Fish escape $\cdot$ Aquaculture $\cdot$ Telemetry $\cdot$ Recapture

\section{INTRODUCTION}

Although the Atlantic cod Gadus morhua L. farming industry has faced numerous challenges over recent years, it has been and remains an important species for the Norwegian aquaculture industry, especially with regard to diversifying the number of species produced. Even though cod production is far below that of salmon and trout in terms of both biomass and value, $>21000 \mathrm{t}$ farmed cod were produced in 2010 (Norwegian Directorate of Fisheries 2010).
A key challenge facing marine-based aquaculture is to reduce the number of fish escaping from sea cages. Cod farming is no exception to this, and the percentage of cod escaping from fish farms has been higher than other species (Jensen et al. 2010). For example, between 2005 and 2010 an annual average $0.16 \%$ of Atlantic salmon Salmo salar L. escaped every year in Norway. Over the same period, an annual average $1.34 \%$ of Atlantic cod escaped, leading to a total of $>1$ million escapees during that period (Norwegian Directorate of Fisheries 2010). Although the majority of escape events are associ- 
ated with extreme weather events or technical or operational failures (Jensen et al. 2010), Atlantic cod can express behaviors that may increase the risk of escapes. Cod exhibit exploratory behaviors that increase the chance of fish detecting a hole and escaping (Hansen et al. 2008). In addition, cod can bite the cage netting materials (Moe et al. 2007, Damsgård et al. 2012), and this biting behavior can weaken the net (Høy et al. 2012). At present, direct evidence of the negative ecological impacts of escaped cod is sparse. It has been shown that cod escapees can mix with wild cod in the fjords and on the spawning grounds (Uglem et al. 2008), and it has also been suggested that they may increase predation pressure on wild salmon smolts during their migratory phase (Brooking et al. 2006, Hedger et al. 2011). Escaped cod may also act as a transmission vector for parasites between wild and farmed fish (Øines et al. 2006). In addition to reducing the risk of escapes by improving farming operations and procedures, effective and operational routines are needed to recapture escapees, mitigating against potential negative ecological impacts and reducing the economic losses associated with escapes.

Telemetry studies performed in Newfoundland and Northern Norway have indicated that escaped adult cod tend to disperse rapidly and far from the farm of origin (Wroblewski et al. 1996, Uglem et al. $2008,2010)$. However, a substantial proportion of the fish remain in the vicinity of the farm during the first few weeks after an escape (Uglem et al. 2008, 2010). It has previously been suggested (Uglem et al. 2008) that a recapture fishery should start as soon as possible after an escape and cover a large area, but with a focus on areas close to the farm and the shoreline. The recapture rates of these adult cod escapees in local commercial fisheries were surprisingly high (28 to $52 \%$ ), even with minor recapture efforts (Uglem et al. 2008).

Information on the post-escape behavior of juvenile farmed cod and their potential for recapture is sparse. Sea ranching studies performed in Norway have shown that reared juvenile cod can be fairly stationary after release (Svåsand et al. 1998, Larsen \& Pedersen 2002), although more variable results on migration patterns have been reported from experiments in other areas such as Denmark (Støttrup et al. 1994) and the Faroe Bank (Fjallstein \& Jákupsstovu 1999). Reported recapture rates from these experiments varied largely between areas, release season, and size at release; in some cases, however, recapture rates were as high as 30\% (Kristiansen et al. 2000; see review by Svåsand et al. 2000), suggesting that a coordinated post-escape fishing program could be a realistic option for the effective recapture of juvenile cod escapees. To our knowledge, the spatiotemporal distribution of juvenile cod escaping from commercial cod farms has not been reported. Such knowledge may provide valuable information for predicting the possible impacts of escapes as well as improving recapture efficiency.

The aim of the present study was to examine the spatiotemporal distribution of juvenile farmed Atlantic cod after a simulated escape from a commercial sea cage. Juvenile cod, tagged with acoustic transmitters, were released from a commercial farm and their movements were monitored using acoustic receivers distributed around the farm and in the fjord. To provide operational data on the viability of different recapture techniques, externally tagged fish were also released at the same farm and recapture attempts were made using various methods.

\section{MATERIALS AND METHODS}

\section{Study area}

The study was carried out at Nordfjord $\left(67^{\circ} 07^{\prime} \mathrm{N}\right.$, $14^{\circ} 17^{\prime}$ E) in Gildeskål, northern Norway (Fig. 1) between 10 September 2010 and 15 March 2011. Nordfjord is a continuation of Beiarnfjord, an arm of the Saltenfjord, and has an average width of about $2.5 \mathrm{~km}$ at its central point, where it reaches depths of around $400 \mathrm{~m}$. The temperature of the water ranged between 8 and $10^{\circ} \mathrm{C}$ in late autumn and between 2 and $5^{\circ} \mathrm{C}$ in winter, and salinity was between 30.5 and 32.8 during the whole study period. Two cod farms were located in the area. The cod escapes simulated in the present study were performed in the northern location (Hammarvika), which we will refer to as the release farm (Farm 1). The second cod farm (Kjerkvika) was situated $\sim 3 \mathrm{~km}$ south of the release farm, and will be referred to as Farm 2. Both farms were situated close to the shoreline $(\sim 150 \mathrm{~m})$ at depths $>200 \mathrm{~m}$. A small local semi-commercial fleet of 5 to 6 fishing boats was operative in the fjord during the study period.

\section{Study animals}

A total of 2801 juvenile Atlantic cod were used in the present study. The fish were hatched at Havlandet Marin Yngel (Florø, Norway) in November 2009 and transferred to the sea cages in Hammarvika (release farm) in late July 2010, at $~ 80 \mathrm{~g}$ body weight. 


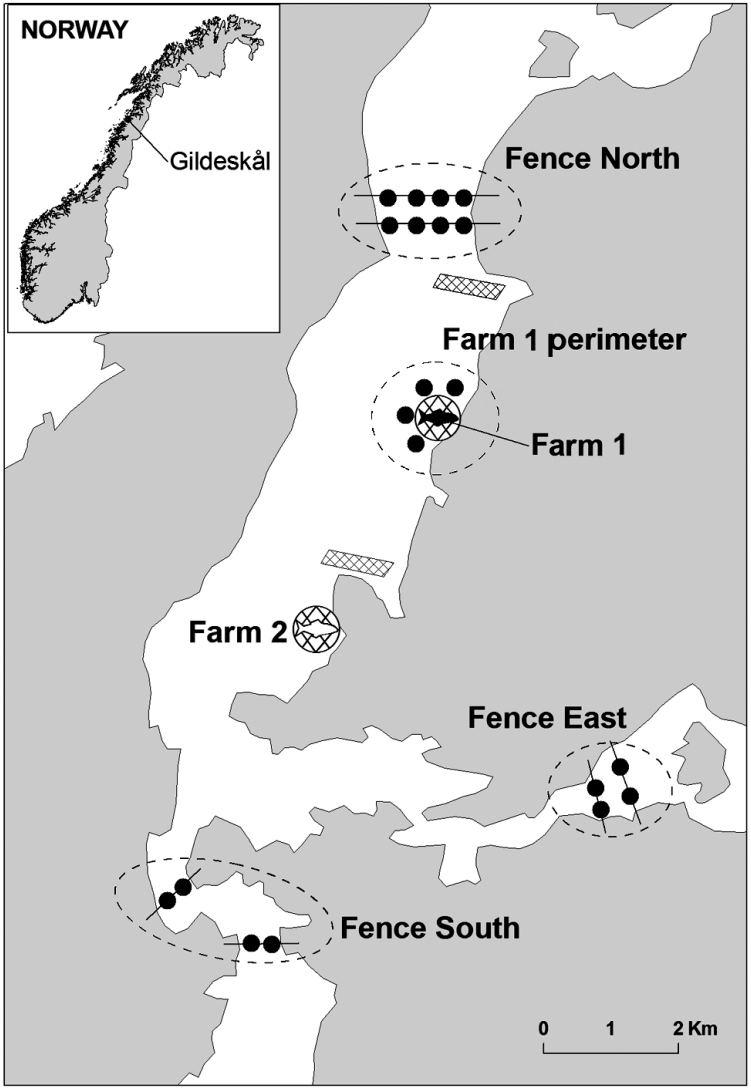

Fig. 1. Study area in Gildeskål, Norway, with receiver locations (•) in different areas; release farm (Farm 1) and fence areas (North, East, South). Dashed lines encircle receivers of a respective area. Double fences are indicated with a line connecting the corresponding receivers. Four additional receivers were deployed, 2 in each farm (not shown). Cross-hatched symbols indicate gill-netting areas

From here, 4 subgroups were taken out at different moments throughout the study: 3 groups of $\sim 1000$ individuals each were collected in September, October, and March for external tagging; another 24 fish were collected in October for acoustic tagging. Exact numbers and sizes of the fish used on each occasion are given in Table 1.

\section{Acoustic telemetry}

The immediate post-escape behavior of 24 juvenile cod (Age-1, average length: $30.8 \pm 1.5 \mathrm{~cm}$ ) was monitored with acoustic telemetry (Table 1). During the day prior to tagging, fish were transferred from the commercial net pens into an adjacent storage pen (circumference: $8 \mathrm{~m}$, depth: $2 \mathrm{~m}$ ). Fish were collected from the storage pen using a hand net and individually immersed in an aqueous solution of metacaine (Finquel, $70 \mathrm{mg} \mathrm{l}^{-1}$ ) for anesthetization immediately before tagging. The fish were placed ventral side up onto a V-shaped surgical table. An incision ( 15 to $20 \mathrm{~mm}$ ) was made on the ventral surface posterior to the pelvic girdle using a scalpel. Prior to each incision, surgical equipment was rinsed in $70 \%$ ethanol and allowed to dry. A coded transmitter (Thelma Biotel; $13 \times$ $26 \mathrm{~mm}$, random pulse interval between 30 and $90 \mathrm{~s}$, weight in air/water: 9.0/5.6 g, estimated lifespan: $639 \mathrm{~d}$, frequency: $69 \mathrm{kHz}$ ) was inserted through the incision and pushed into the body cavity in front of the pelvic girdle. The incision was closed with 2 or 3 independent silk sutures (3/0 Ethicon). No external tags were attached to these fish. After surgery, the fish was transferred to a small recovery pen $\left(2.5 \mathrm{~m}^{3}\right)$ adjacent to the commercial net pen. No mortality was observed after tagging. All handling and tagging was conducted according to the Norwegian Regulation on Animal Experimentation (REG 1996-01-15 §23; FOR 1996-01-15 nr 23: Forskrift om forsøk med dyr. Available at www.lovdata.no/cgi-wift/ldles?doc=/sf/sf/sf19960115-0023.html). The fish were released into the sea after $48 \mathrm{~h}$ recovery (on 8 October) by slowly lowering one side of the net. No abnormal swimming patterns were observed at the moment of release.

\section{Configuration of receiver array}

The movements and distribution of the fish tagged with acoustic transmitters were recorded

Table 1. Gadus morhua. Overview of released juvenile farmed cod groups, including fish equipped with acoustic (Acoust.) and external (Ext.) tags. Recapture rates indicated as percentage of the total number of fish in each group. Reward program: recaptures reported by professional and recreational fishers encouraged by the reward program $;$-: not applicable

\begin{tabular}{|c|c|c|c|c|c|c|c|c|}
\hline \multirow[t]{2}{*}{ Group } & \multirow[t]{2}{*}{$\mathrm{n}$} & \multirow{2}{*}{$\begin{array}{l}\text { Total length }(\mathrm{cm}) \\
\text { mean } \pm \mathrm{SD}\end{array}$} & \multirow{2}{*}{$\begin{array}{l}\text { Weight }(g), \\
\text { mean } \pm \text { SD }\end{array}$} & \multirow{2}{*}{$\begin{array}{l}\text { Release } \\
\text { date }\end{array}$} & \multicolumn{4}{|c|}{ - Recaptured (\%) - } \\
\hline & & & & & $\begin{array}{l}\text { Live } \\
\text { recapture }\end{array}$ & Nets & $\begin{array}{c}\text { Reward } \\
\text { program }\end{array}$ & Total \\
\hline Ext. 1 & 1033 & $24.8 \pm 1.8$ & $171.7 \pm 508$ & 16 Sep 2010 & 0 & 0 & 0 & 0 \\
\hline Acoust. & 24 & $30.8 \pm 1.5$ & $392.8 \pm 55.4$ & 8 Oct 2010 & - & - & - & - \\
\hline Ext. 2 & 874 & $28.9 \pm 2.5$ & $331.2^{\mathrm{a}}$ & 10 Oct 2010 & 0 & 4.46 & 0.57 & 5.03 \\
\hline Ext. 3 & 870 & $36.3 \pm 3.2$ & $691.3 \pm 198.9$ & 20 Mar 2011 & 0 & 0.11 & 0.34 & 0.45 \\
\hline
\end{tabular}


using 24 receivers (Vemco, model VR2) distributed in 6 defined areas of the fjord: Fence North (8 receivers), Fence South (4 receivers), Fence East (4 receivers), release farm (Farm 1, 2 receivers), Farm 1 perimeter (4 receivers), and Farm 2 (2 receivers) (Fig. 1). The fences were set as double lines of receivers and covered every possible exit from the fjord; $_{i}$ the purpose of these double fences was to provide information on directional movements: if a fish was detected in sequence between the inner and outer side of a fence, and was never detected again in the inner part, the fish was defined has having left the delimited study area. Depth at the deployment sites varied between 30 and $350 \mathrm{~m}$. Receivers were typically attached to anchored ropes, except for the receivers situated at the fish farms, which were hung on ropes from the sea cages $(10 \mathrm{~m}$ depth). A series of range tests were performed, and the average detection range of the receivers was determined to be $\sim 700 \mathrm{~m}$ in radius. Therefore, the distance between receivers in each fence was $<500 \mathrm{~m}$. All receivers recorded the transmitter identification code, date, and time of detection. During the first 35 post-release days, every receiver in the array was fully operative. After this point, only the receivers at the site of the release and the farm perimeter remained operative, recording until late March 2011 (total of $20 \mathrm{wk}$ ). All the other receivers were progressively pulled out of the water after $35 \mathrm{~d}$ due to ice-forming on the fjord.

\section{Recapture of escapees}

In addition to the fish equipped with acoustic transmitters, 3 separated simulated escapes of $\sim 850$ to 1000 externally tagged juvenile cod were performed at the release farm (Table 1). On each occasion, fish were immersed in an aqueous solution of metacaine (Finquel, $70 \mathrm{mg} \mathrm{l}^{-1}$ ) for light anesthetization immediately before tagging. External T-bar tags (Floy Tag \& $\mathrm{Mfg}$ ) were inserted in front of the dorsal fin according to Dell (1968). The fish were allowed to recover for $24 \mathrm{~h}$ before being released by carefully lowering one side of the net in the recovery pens.

No recapture efforts were initiated after the first simulated escape, so these fish would act as a longterm post-escape group. Intensive recapture efforts were initiated after the second and third simulated escapes. In order to simulate a real situation, the start of the recapture programs was delayed $24 \mathrm{~h}$ from the moment the fish were released. Recapture methods included the use of cod pots, fyke nets, a 'smart pen', and a large crane-assembled dip net. The cod pots consisted of 2 horizontal successive chambers and are described in more detail in Furevik (1997). Commercial fish-feed pellets were used as bait. A total of 6 pots of 3 different sizes $\left(1.8,8\right.$, and $\left.14 \mathrm{~m}^{3}\right)$ were distributed around the farm after the escapes, suspended at $\sim 6 \mathrm{~m}$ depth. Pots were submerged for $6 \mathrm{~d}$ in each trial, with routine checks of the contents of each pot performed every $48 \mathrm{~h}$.

Two fyke nets were permanently mounted and were operational for the duration of the study. These entrapments consist of a leading net $(0.8 \times 5 \mathrm{~m}$; $25 \mathrm{~mm}$ mesh size) connected to a $3 \mathrm{~m}$ long tunnel with 4 chambers; the first 2 chambers act as a 1-way passage for fish entering the trap. The fyke nets were moored onto the net wall of 2 different sea cages, at 1 to $3 \mathrm{~m}$ depth, with the leading net running parallel to the wall of the commercial cages. The traps were checked on a weekly basis.

The 'smart pen' consisted of a full-size sea net pen (90 m circumference, $25 \mathrm{~m}$ deep) with a circular 1-way-entrance gate placed on one side of the cage, $4 \mathrm{~m}$ under the surface. By distributing commercial fish feed into the sea around the cages via a slowmoving boat, large numbers of fish were guided towards the entrance of the smart pen. When the fish swam through the tunnel and into the pen, the gate was closed to prevent the fish escaping again. The smart pen was located at the southern farm (Kjerkvika, Farm 2) for $\sim 2$ wk after the second and third releases.

The large dip net consisted of 2 metal rings $(3.5 \mathrm{~m}$ diameter) covered with a resistant netting and attached to 4 ropes, from which it could be hooked and operated with a crane. The strategy employed was very similar to that of the 'smart pen': it was lowered down to $7-8 \mathrm{~m}$ in the farm's vicinity; then large amounts of fish feed were distributed around the trap to attract the fish to the dip net. When the density of fish was high enough, the dip net was quickly lifted and the catch collected with standard hand nets. Both the smart pen and the large dip net were operated by the cod farm staff a minimum of 3 times after each escape.

Two local semi-professional fishing vessels were hired to recapture the escapees with gill nets. Following the second release (October), 10 sinking nets with a mesh size of $37 \mathrm{~mm}$ were used. The nets were $2.2 \mathrm{~m}$ deep and $37 \mathrm{~m}$ long and were tied together in 2 fleets of 5 nets (i.e. giving a fleet length of $185 \mathrm{~m}$ ). One of the fleets was deployed $2 \mathrm{~km}$ north of the release site at depths ranging from 10 to $45 \mathrm{~m}$, while the other fleet was deployed 
$2 \mathrm{~km}$ south of the release farm, at similar depths (Fig. 1). In both cases, nets were set perpendicular to the coast in a line from shallow to deep waters. A similar deployment was used for the second recapture (March 2011); in this case, 20 nets with a mesh size of $60 \mathrm{~mm}$ and a length of $27.5 \mathrm{~m}$ were combined in 4 fleets of 5 nets each. The nets were set in the same way and position as in the first recapture, but 2 fleets per location were set on this occasion. The distance between fleets in the same location was $\sim 500 \mathrm{~m}$. In both trials, nets were set early in the morning and retrieved after the following morning. This process was repeated 3 times, giving a total deployment time of $72 \mathrm{~h}$ per fleet over a $6 \mathrm{~d}$ post-escape time span.

Posters with information about the project and the recapture reward were also distributed in strategic points around the area of study in order to stimulate the local community to report any recapture.

\section{Data analyses}

As the acoustic transmitters used to tag the juvenile farmed cod were not equipped with a depth sensor, it was difficult to determine mortality. Instead, the term 'stationary' is used. A fish was regarded as stationary when it was detected continuously throughout the whole study period by the same receiver. Data from the acoustic receivers were pooled into 6 separated zones: fences north, south, and east; release farm (Farm 1); Farm 1 perimeter; and Farm 2. Detection of a fish by at least 1 of the receivers within a zone was defined as presence in the area. Departure from the release farm vicinity was defined as the first time a fish was not recorded by any of the 2 receivers deployed in the farm for more than $24 \mathrm{~h}$. To avoid false signals generated by environmental noise, single detections within $1 \mathrm{~h}$ were considered as erroneous unless there was a clear indication that the detection was valid (frequent detection during the same day and also by nearby receivers). Detections in the farm perimeter and in the fences were further separated into 'littoral' (when detection corresponds to the receivers closer to the shoreline in either area) and 'pelagic' detections. In order to investigate the habitat use by the escapees, differences in the number of detections by littoral versus pelagic receivers were analyzed using a paired $t$-test. Statistical significance was set at $p<0.05$. All statistical analyses and graphics were performed using $\mathrm{R}$ (version 2.14.1) and RStudio.

\section{RESULTS}

\section{Telemetry study}

All tagged fish were detected at the release farm after release. Three $(12.5 \%)$ were defined as stationary (i.e. suspected dead). After release, the non-stationary fish dispersed rapidly from the release farm: the median residence time before first departure was $2 \mathrm{~d}$, and $85 \%$ of the fish left the release farm within $1 \mathrm{wk}$ after release (Fig. 2). Most fish (20 out of 21) left the farm along the shoreline and were detected by 1 of the 2 littoral receivers at the farm perimeter rather than by the receivers located further away from the shore. There was a non-significant trend for a higher proportion of the fish to disperse in a northerly direction compared to those moving southwards (14 vs. 6 fish, binomial test, $\mathrm{p}=0.052$ ).

Six of the fish were detected in Fence North, 2 at Farm 2, and none at Fence East and Fence South (Fig. 3). Only 1 individual was recorded leaving the fjord, departing from the study area through Fence North 3 wk after release. Five of the fish showed a strong affinity for the area close to the release farm and spent most of the study time within the detection range of the farm receivers. Another 2 fish were primarily detected around Fence North, while the remaining fish $(70 \%)$ spent most of the study time outside the detection range of any receiver in the fjord. When detected in the farm perimeter and/or Fence North, the number of detections per fish was significantly higher in the littoral receivers compared with offshore receivers (paired $t$-test, $\mathrm{p}=0.017$ ). Some individuals were detected in different zones of the fjord within the same day. One individual was

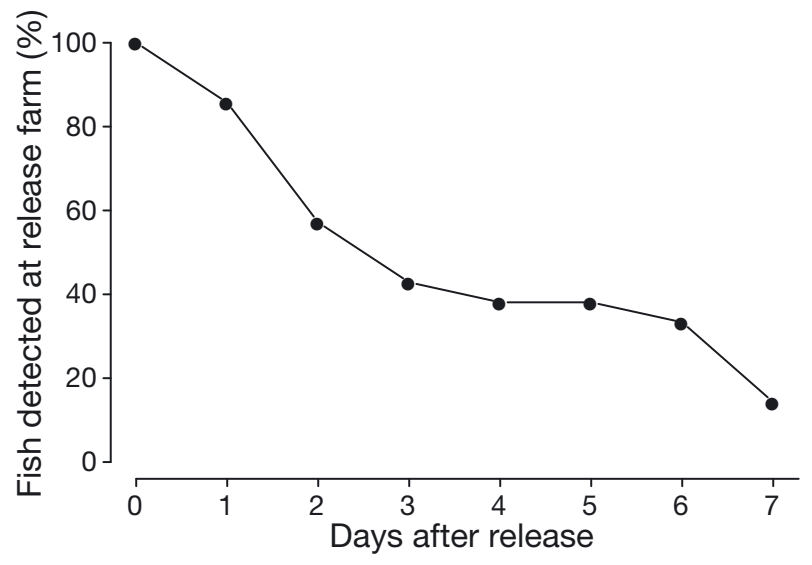

Fig. 2. Gadus morhua. Proportion of released juvenile cod tagged with acoustic transmitters $(n=21)$ detected in close proximity to the release farm within the first week after release 


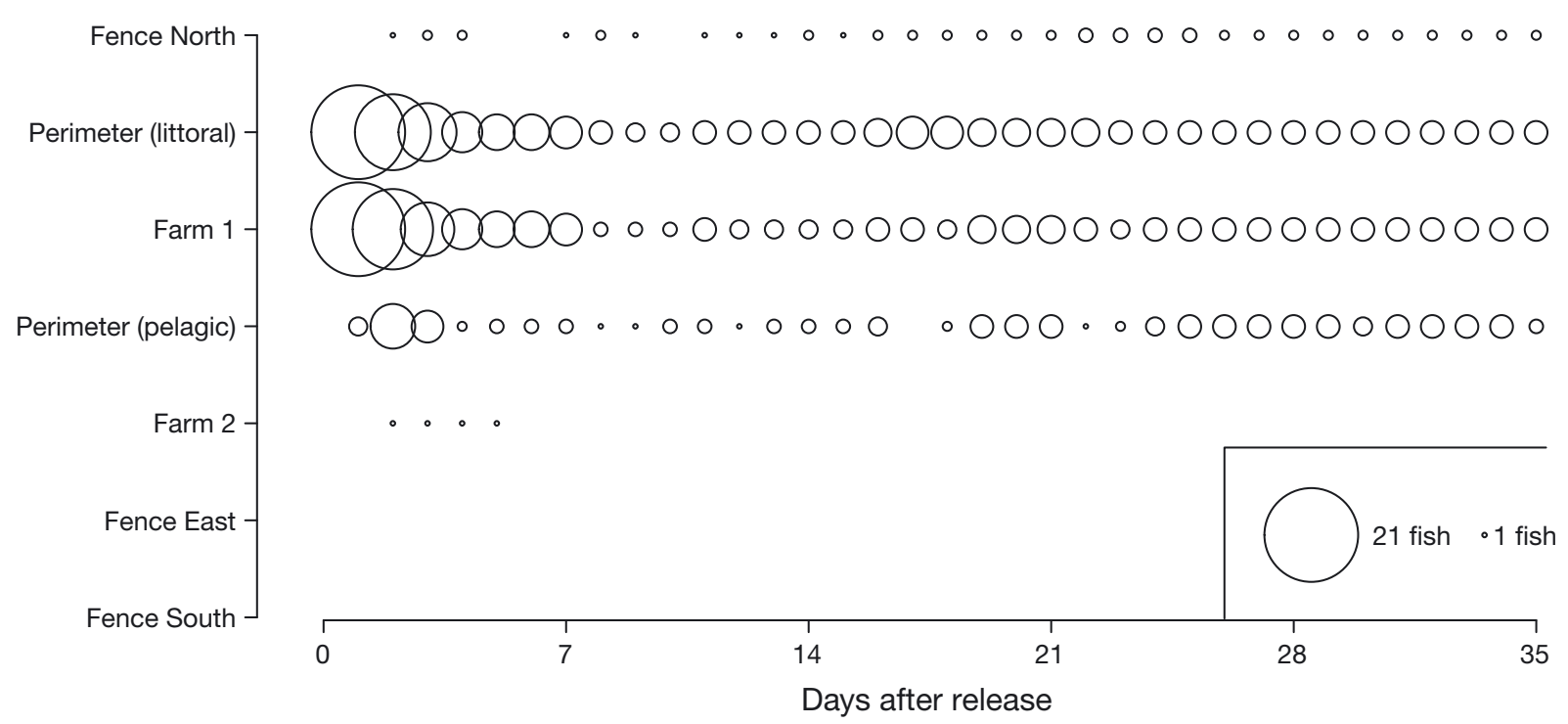

Fig. 3. Gadus morhua. Spatiotemporal distribution of released juvenile farmed Atlantic cod tagged with acoustic transmitters during the first $5 \mathrm{wk}$ after release (only non-stationary fish included, $\mathrm{n}=21$ ). The size of the circles shows the proportions of fish observed in the different zones of the fjord (see Fig. 1). Note that a fish could be detected in several zones during the same day

detected in 3 different zones during the first week after the escape; it left the release farm during the second day post-escape, made a short visit to Farm 2, returned to the release farm area on Day 5, and dispersed north on Day 7. It was detected on Day 7 by the receivers in Fence North before being caught by the collaborating fishers with the gill nets $\sim 2 \mathrm{~km}$ north of the release farm on the same day.

The percentage of acoustically tagged fish detected at the release farm was relatively stable (Fig. 4). After the first week post-escape, when the majority of the fish dispersed to other areas of the fjord, between 14 and $34 \%$ of the non-stationary fish were detected weekly at the release farm for the following 5 mo.

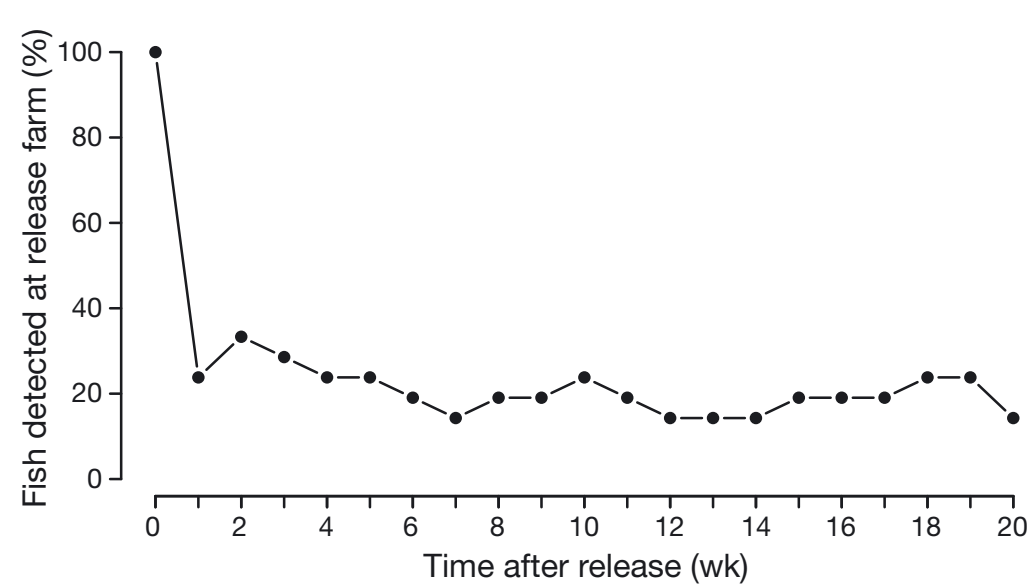

Fig. 4. Gadus morhua. Proportion of released juvenile cod tagged with acoustic transmitters $(n=21)$ detected in close proximity to the release farm during the whole study period $(20 \mathrm{wk})$

\section{Recapture of escapees}

The live recapture methods captured large numbers of saithe Pollachius virens and both wild and previously escaped (feral) cod in the vicinity of the fish farm, but none of the tagged juveniles were recaptured. A total of 39 tagged cod juveniles were recaptured in the gill nets after the second release, and 30 of these fish were captured in the nets deployed north of the release farm. All of these fish belonged to the second release group. The by-catch in the nets outnumbered the recapture of escapees; around 500 individuals from non-targeted species were captured, with crabs Cancer pagurus, saithe, and cod (wild and feral) being the most abundant species (Fig. 5). The size of the saithe caught in the nets was 17 to $42 \mathrm{~cm}$, while the non-tagged cod ranged from 25.5 to $82 \mathrm{~cm}$. The by-catch also included other fish species, including tusk Brosme brosme, haddock Melanogrammus aeglefinus, lemon sole Microstomus kitt, pollack Pollachius pollachius, mackerel Scomber scombrus, halibut Hippoglossus hippoglossus, flounder Platichthys flesus, and lumpsucker Cyclopterus lumpus. Only 1 tagged juvenile was recaptured during the second gill-netting trial in March 2011. By-catch was also substantially lower than in October (Fig. 5). Inspection of the stomach contents of the recaptured escapees showed an average 


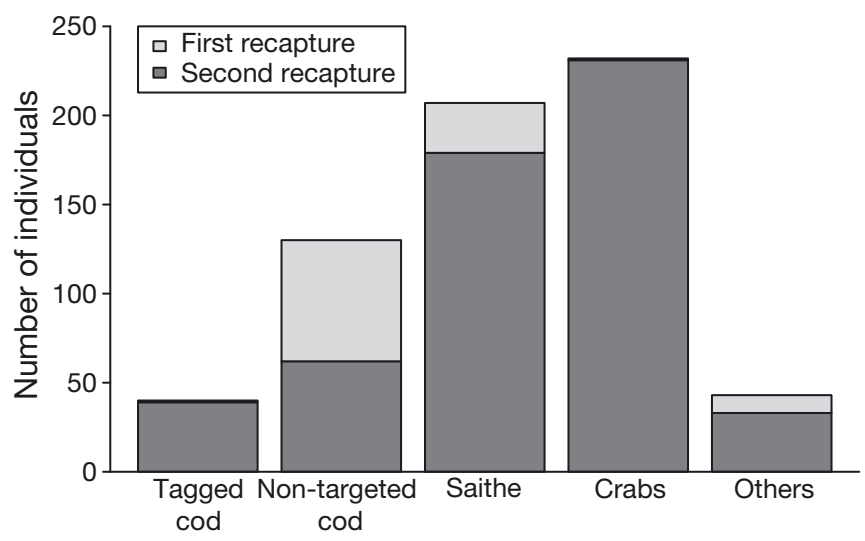

Fig. 5. Gadus morhua, Pollachius virens, and Cancer pagurus. Number of individuals caught in the gill nets during the first and second recapture trials in October 2010 and March 2011, respectively. 'Tagged cod' indicates recapture of intentionally released juvenile cod marked with external tags; by-catch specified by species (see 'Recapture of escapees' for species included in 'Others')

stomach filling of $5 \%$. In every case, the stomach contents consisted of molluscs exclusively; no feedpellet remains were found.

A total of 8 recaptured tagged cod were reported via the reward program by local fishers. None of the fish were from the first simulated release, 5 fish were from the second release, and 3 from the third. All these recaptures occurred within $2 \mathrm{~km}$ from the release farm, in a time span from $6 \mathrm{~d}$ to 6 mo postrelease. The reward program also stimulated a considerable effort from the farm staff for reporting tagged fish that were collected from the stomach of predatory saithe and cod jigged around the net pens. Within $2 \mathrm{~d}$ of the first escape and with a modest fishing effort, 56 potential predators were caught and 21 tags were found in their stomachs. During the following week, the number of recovered tags increased to 88. The catch of potential predators was repeated after the second escape. This time, 160 predators were examined, and 22 tags found; these tags belonged to cod from both the first (17 tags) and the second (5 tags) release group. Thus, a total of 105 juvenile cod from the first release group and 5 from the second group were reported as predated upon via data sourced from stomach content analyses of large wild fish caught at the farms.

In summary, from a total of 2777 juvenile cod that were released for this study, only 48 of them (1.73\%) were recaptured, another 110 (3.9\%) escapees were found in the stomachs of predators, and the remaining $94.3 \%$ were unaccounted for $1 \mathrm{yr}$ after the first escape event was performed.

\section{DISCUSSION}

In agreement with previous studies on escaped cod (Uglem et al. 2008, 2010), many of the tagged juveniles left the release farm rapidly and were more frequently detected close to the shore than further out in the fjord. In the wild, young cod (Age 0 to 2) utilize shallow coastal waters as nurseries, partly as an adaptation to avoid predation (Gotceitas et al. 1995, Svendsen 1995, Linehan et al. 2001, Cote et al. 2004). The finding that the released juveniles move rapidly from the farm location in deeper water and into the more shallow littoral area might thus be an adaptive behavioral response. Approximately 25\% of the acoustically tagged escapees were detected on a regular basis at the release farm. As the farm was located very close to the shoreline $(<150 \mathrm{~m})$, these detections may not necessarily mean that the fish stayed close to the cages; it could indicate that the fish stayed in the littoral zone close the farm, as this was within the detection range of the receivers. In addition, the fact that the fish were detected more frequently by the littoral receivers compared to the offshore receivers supports the possibility that the tagged fish preferred to stay in the littoral zone after escaping. During the first 5 wk after the simulated escape, only 1 of 21 fish left the fjord. A strong sitefidelity has been previously described for both wild (Svendsen 1995, Cote et al. 2004) and reared (Svåsand et al. 1998, Larsen \& Pedersen 2002) juvenile cod, and these findings are supported by the results of the present study.

Results from the recapture program support the conclusions from the telemetry data. No tagged juveniles were recaptured with any of the live recapture methods tested in the immediate vicinity of the farm despite the considerable recapture effort undertaken during the study. A relatively large number of tagged cod juveniles were found in the stomachs of a relatively small sample of large saithe and cod (length $\sim 60$ to $100 \mathrm{~cm}$ ) caught at the farm. The presence of predatory fish around the farm was not unexpected, as large aggregations of piscivorous fish have been previously reported around fish farms in Norway (Dempster et al. 2009, 2010). Hence, aggregated fish may serve not only as a filter for uneaten fish feed (Vita et al. 2004, Dempster et al. 2005) but also for small escaped farmed fish.

According to Scharf et al. (2000), the average preferred prey lengths for the saithe and cod that were caught at the farm are about 13 and $11 \mathrm{~cm}$, but they can also consume prey up to 25 and $31 \mathrm{~cm}$, respectively. The estimated maximum prey size for saithe is 
around 25 to $30 \mathrm{~cm}$ (Scharf et al. 2000, Floeter \& Temming 2005). Even though predatory Atlantic cod can predate upon much bigger prey (up to $70 \mathrm{~cm}$; Scharf et al. 2000), they rarely eat fish bigger than 30 to $35 \mathrm{~cm}$ (Neuenfeldt \& Köster 2000, Scharf et al. 2000, Juanes 2003). Thus, the first release group (average length: $<25 \mathrm{~cm}$ ) were of a size that was within the prey window for the aggregated wild fish, and a high predation rate could be expected for this release group. This assumption was confirmed, as $10 \%$ of these tags were found in the stomachs of a relatively small sample of predators. It is then reasonable to assume that this first release group, which should have acted as a long-term post-escape group, was strongly depleted shortly after escape due to heavy predation. The fact that only $0.6 \%$ of the fish from the second release group (average length: $29 \mathrm{~cm}$ ) were found in predator stomachs supports the suggestion that predation pressure from predators aggregating around fish farms may decrease as the size of the escaped fish increases. This finding is also important for evaluating the telemetry results. The acoustic transmitters were not equipped with a depth sensor and it was not possible to evaluate if the released juveniles were eaten by the aggregated predators. Although we cannot exclude the possibility that acoustically tagged fish were eaten by the aggregated predators around the farm, the larger size of the fish used in the telemetry experiment (average length: $31 \mathrm{~cm}$ ) may indicate that the predation of these fish was much less severe than the predation pressure upon the first externally tagged group of fish. Studies on the behavior of wild fish aggregated around commercial fish farms in Norway suggest that wild saithe (the most abundant species found to aggregate around commercial fish farms in Norway) show a strong and long-lasting attraction to the farms, a high frequency of movements between neighbor farms, and a extensive ranging (10s of $\mathrm{km})$ behavior within the fjord (Uglem et al. 2009). None of these behaviors were shown by the acoustically tagged fish in the present study, which is further evidence against the possibility of predation.

Recapture efforts carried out in the shallow waters close to the shoreline were more effective than recapture efforts carried out close to the fish farm. Respectively 4.46 and $0.11 \%$ of the escapees from the second and third release group were caught in gill nets deployed in the littoral area. This finding corresponds with the telemetry results, and supports our suggestion that juvenile cod may seek protection in shallow waters close to the shoreline following escape. The lower recapture rates from the third release group may reflect a high variability in the recapture efficiency of the nets or it may be a reflection of potential differences in the behavior of small and large cod. Previous studies have shown that smaller juveniles tend to occupy shallow waters between 10 and $30 \mathrm{~m}$ depth (Svendsen 1995, Cote et al. 2004), while older fish are generally found in deeper waters (Sinclair 1992, Dalley \& Anderson 1997).

The large by-catch that occurred when using gill nets reduced the efficiency of the recapture method. The combination of low recapture rates, operational difficulties, and a large by-catch of wild fish imply that upscaling of gill-net fishing is a questionable strategy for an organized recapture fishery for escaped juvenile cod. There were no reported recaptures in the gill nets used by the semi-commercial fishers operating in the fjord; this probably reflects a mismatch between the size of the standard cod nets with large mesh sizes used in the fjord and the small size of the tagged fish $(<40 \mathrm{~cm}$ total length). The low number of recaptures reported through the reward program (Table 1) could also be a consequence of the unsuitability of common recreational fishing gear for catching juveniles. The coastal location of the release site might also have reduced the chances of recapture. Svåsand et al. (2000) described significant variations in recapture rates between areas, with recapture rates of fish released in open coastal areas being generally lower when compared with fish released inside fjords.

In conclusion, the present study indicates that escaped juvenile cod might experience a high sizerelated predation pressure in the immediate vicinity of sea cages and may therefore seek shelter in shallower waters in the littoral zone. Even though the escapees disperse rapidly from the farms, they can stay relatively close $(<10 \mathrm{~km})$ to the farm during the first 2 mo following an escape. This suggests a high potential for recapture when the effort is focused on the littoral area and not in the immediate vicinity of the farm. However, extrapolation of results from field studies from one particular setting to another has to be carefully made, as natural environments involve countless different factors whose magnitude and effects are not always easy to predict. In the present study, the post-escape behavior of juvenile cod escapees at a particular moment and in a specific place is analyzed and conclusions are drawn in the context of this particular scenario. Spatiotemporal variations in the behavior of the escapees may occur, and results from this study should not be generalized.

The small mesh size of the gill nets needed for the recapture of juveniles seems to be a bottleneck for 
the efficiency of this recapture method. Also, the high by-catch rates and the subsequent high workload suggest that this method may be inappropriate for the recapture of escapees following large-scale escape events from commercial farms. An alternative which avoids high mortalities of non-targeted species could be the deployment of cod pots in the littoral area close to the farm. However, the efficiency of this approach needs to be investigated. In summary, even with the suite of recapture methods evaluated in this study, the recapture rates achieved were too low to justify the efforts devoted to recapture. This emphasizes the need to prevent escape incidents by improving farming technology and operational routines. In other words, the battle to avoid possible negative ecological effects of escaped juvenile farmed Atlantic cod should take place before the cod escape from the sea cages.

Acknowledgements. We thank Tor H. Evensen, Philip James, Christian Dalen, Cristina Velasco, and Begoña De Cabo for their help and assistance in the field. We also thank the staff members at Cod Farmers and the local fishers in Gildeskål for their collaboration. This research was funded by the European Union's 7th Research Framework Prevent Escape project (no. 226885).

\section{LITERATURE CITED}

Brooking P, Doucette G, Tinker S, Whoriskey FG (2006) Sonic tracking of wild cod, Gadus morhua, in an inshore region of the Bay of Fundy: a contribution to understanding the impact of cod farming for wild cod and endangered salmon populations. ICES J Mar Sci 63:1364-1371

> Cote D, Moulton S, Frampton PCB, Scruton DA, Mckinley RS (2004) Habitat use and early winter movements by juvenile Atlantic cod in a coastal area of Newfoundland. J Fish Biol 64:665-679

> Dalley EL, Anderson JT (1997) Age-dependent distribution of demersal juvenile Atlantic cod (Gadus morhua) in inshore/offshore northeast Newfoundland. Can J Fish Aquat Sci 54:168-176

Damsgård B, Høy E, Uglem I, Hedger RD, Izquierdo-Gomez D, Bjørn PA (2012) Net-biting and escape behaviour in farmed Atlantic cod Gadus morhua: effects of feed stimulants and net traits. Aquacult Environ Interact 3:1-9

Dell MB (1968) A new fish tag and rapid cartridge-fed applicator. Trans Am Fish Soc 97:57-59

> Dempster T, Fernandez-Jover D, Sanchez-Jerez P, Tuya F, Bayle-Sempere J, Boyra A, Haroun RJ (2005) Vertical variability of wild fish assemblages around sea-cage fish farms: implications for management. Mar Ecol Prog Ser 304:15-29

> Dempster T, Uglem I, Sanchez-Jerez P, Fernandez-Jover D, Bayle-Sempere J, Nilsen R, Bjørn PA (2009) Coastal salmon farms attract large and persistent aggregations of wild fish: an ecosystem effect. Mar Ecol Prog Ser 385: $1-14$

Dempster T, Sanchez-Jerez P, Uglem I, Bjørn PA (2010)
Species-specific patterns of aggregation of wild fish around fish farms. Estuar Coast Shelf Sci 86:271-275

Fjallstein I, Jákupsstovu SH (1999) Release, recapture and migration of reared Atlantic cod (Gadus morhua L.) on the Faroe Islands. In: Howell BR, Moksness E, Svåsand T (eds) Stock enhancement and sea ranching. Fishing News Books, Blackwell Science, Oxford, p 231-256

- Floeter J, Temming A (2005) Analysis of prey size preference of North Sea whiting, saithe, and grey gurnard. ICES J Mar Sci 62:897-907

Furevik DM (1997) Development of a new cod pot and comparative trials with commercial pots and longline. Cons Int Explor Mer Working Group on Fishing Technology and Fish Behavior. Hamburg, 14-17 April

> Gotceitas V, Fraser S, Brown JA (1995) Habitat use by juvenile Atlantic cod (Gadus morhua) in the presence of an actively foraging and non-foraging predator. Mar Biol 123:421-430

Hansen LA, Dale T, Uglem I, Aas K, Damsgård B, Bjørn PA (2008) Escape related behavior of Atlantic cod (Gadus morhua L.) in a simulated farm situation. Aquacult Res 40:26-34

> Hedger RD, Uglem I, Thorstad EB, Finstad B and others (2011) Behaviour of Atlantic cod, a marine fish predator, during Atlantic salmon post-smolt migration. ICES J Mar Sci 68:2152-2162

> Høy E, Volent Z, Moe-Føre H, Dempster T (2012) Loads applied to aquaculture nets by the biting behavior of Atlantic cod (Gadus morhua). Aquacult Eng 47:60-63

> Jensen $\varnothing$, Dempster T, Thorstad EB, Uglem I, Fredheim A (2010) Escapes of fishes from Norwegian sea-cage aquaculture: causes, consequences and prevention. Aquacult Environ Interact 1:71-83

Juanes F (2003) The allometry of cannibalism in piscivorous fishes. Can J Fish Aquat Sci 60:594-602

Kristiansen TS, Otterå H, Svåsand T (2000) Size-dependent mortality of juvenile Atlantic cod, estimated from recaptures of released reared cod and tagged wild cod. J Fish Biol 56:687-712

> Larsen LH, Pedersen T (2002) Migration, growth and mortality of released reared and wild cod (Gadus morhua) in Malangen, northern Norway. Sarsia 87:97-109

> Linehan JE, Gregory RS, Schneider DC (2001) Predation risk of age-0 cod (Gadus) relative to depth and substrate in coastal waters. J Exp Mar Biol Ecol 263:25-44

Moe H, Dempster T, Sunde LM, Winther U, Fredheim A (2007) Technological solutions and operational measures to prevent escapes of Atlantic cod (Gadus morhua) from sea-cages. Aquacult Res 38:91-99

> Neuenfeldt S, Köster FW (2000) Trophodynamic control on recruitment success in Baltic cod: the influence of cannibalism. ICES J Mar Sci 57:300-309

Norwegian Directorate of Fisheries (2010) Statistikk fra akvakultur. www.fiskeridir.no/statistikk/akvakultur

Øines Ø, Simonsen JH, Knutsen JA, Heuch PA (2006) Host preference of adult Caligus elongatus Nordmann in the laboratory and its implications for Atlantic cod aquaculture. J Fish Dis 29:167-174

Scharf FS, Juanes F, Rountree RA (2000) Predator size-prey size relationships of marine fish predators: interspecific variation and effects of ontogeny and body size on trophic-niche breadth. Mar Ecol Prog Ser 208:229-248

> Sinclair A (1992) Fish distribution and partial recruitment: the case of eastern Scotian Shelf cod. J Northwest Atl Fish Sci 13:15-24 
Støttrup JG, Nielsen JR, Krog C, Ramussen K (1994) Results on the extensive production of North Sea cod, Gadus morhua L., and their growth and distribution subsequent to release in the Limfjord, Denmark. Aquacult Fish Manag 25(Suppl 1):143-159

Svåsand T, Kristiansen TS, Pedersen T, Salvanes AGV, Engelsen R, Nødtvedt M (1998) Havbeite med torskartsrapport. Final report to the Research Council of Norway. Institute of Marine Research, Bergen (in Norwegian with English summary)

Svåsand T, Kristiansen TS, Pedersen T, Salvanes AGV, Engelsen R, Naevdal G, Nødtvedt M (2000) The enhancement of cod stocks. Fish Fish 1:173-205

Svendsen YS (1995) Tracking of juvenile cod (Gadus morhua L.) in northern Norway using acoustic tags. Fish Res 23:311-318

Uglem I, Bjørn PA, Dale T, Kerwath S and others (2008) Movements and spatiotemporal distribution of escaped

Editorial responsibility: Marianne Holmer,

Odense, Denmark farmed and local wild Atlantic cod (Gadus morhua L.). Aquacult Res 39:158-170

Uglem I, Dempster T, Bjørn PA, Sanchez-Jerez P, Økland F (2009) High connectivity of salmon farms revealed by aggregation, residence and repeated movements of wild fish among farms. Mar Ecol Prog Ser 384:251-260

Uglem I, Bjørn PA, Mitamura H, Nilsen R (2010) Spatiotemporal distribution of coastal and oceanic Atlantic cod Gadus morhua sub-groups after escape from a farm. Aquacult Environ Interact 1:11-19

Vita R, Marín A, Madrid JA, Jiménez-Brinquis B, Cesar A, Marín-Guirao L (2004) Effects of wild fishes on waste exportation from a Mediterranean fish farm. Mar Ecol Prog Ser 277:253-261

Wroblewski JS, Smedbol RK, Taggart CT, Goddard SV (1996) Movements of farmed and wild Atlantic cod (Gadus morhua) released in Trinity Bay, Newfoundland. Mar Biol 124:619-627

Submitted: April 23, 2012; Accepted: October 27, 2012

Proofs received from author(s): January 21, 2013 